\title{
Pequeno monstro e leviano: infância e adolescência de Mário Peixoto
}

\author{
[ Little monster and frivolous: childhood and teenage years of Mário Peixoto
}

\section{Denilson Lopes ${ }^{\mathrm{I}}$}

Este ensaio só foi possível graças ao material pesquisado no Arquivo Mário Peixoto e ao apoio do Conselho Nacional de Desenvolvimento Científico e Tecnológico (CNPq).

\begin{abstract}
RESUMO • Pouco conhecidas são a infância e a adolescência do diretor e escritor Mário Peixoto (I908-I992) nos anos I9Io e I920. Por isso a apresentação comentada de partes do seu diário inédito Cadernos verdes referentes a esses momentos de sua vida tem o importante papel de revelar sua formação para outros pesquisadores. São duas partes. Uma se refere à infância em sua casa no Rio de Janeiro. É uma experiência solitária dentro de uma família tradicional e decadente de pessoas silenciosas. A segunda parte, constituída sobretudo por cartas de sua prima Genoca, é um mundo aberto entre o Rio de Janeiro e Petrópolis de passeios, festas e fofocas sobre parentes e amigos. PALAVRASCHAVE • Mário Peixoto; infância; adolescência; diário. ABSTRACT . The childhood and teenage
\end{abstract}

years of the film director and writer Mário Peixoto (I908-I992) are little known. Because of that, the commented presentation of some parts of his unpublished journal "Cadernos verdes" concerning these moments of his life has the important role of revealing his coming of age for other researchers. There are two parts. One is concerned with his childhood basically connected with his house at Rio de Janeiro. It is a lonely experience inside a traditional and decadent family made up of silent people. The second part, consisting mainly by the letters of his cousin Genoca, is an opened world between Rio de Janeiro and Petrópolis full of visits, parties and gossips about relatives and friends. - KEYWORDS · Mário Peixoto; childhood; teenage years; journal.

Recebido em 9 de julho de 2020

Aprovado em 2 de novembro de 2020

LOPES, Denilson. Pequeno monstro e leviano: infância e adolescência de Mário Peixoto. Revista do Instituto de Estudos Brasileiros, Brasil, n. 77, p. 184-203, dez. 2020.

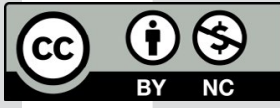

DOI: https://doi.org/Io.II6o6/issn.23I6-90IX.vii77pI84-203

I Universidade Federal do Rio de Janeiro (UFRJ, Rio de Janeiro, RJ, Brasil). 
Pouco sabemos da infância e adolescência de Mário Peixoto antes de sua ida para a Inglaterra. Talvez por isso seu registro em Cadernos verdes (I933) seja de especial interesse para voltar atrás no tempo, no esforço de ler seu diário. A infância entre casa, escola e igreja é apresentada em fragmentos curtos em primeira pessoa, desarticulados, com comentários, anotações, às vezes, posteriores ao próprio tempo em que foram escritos. São sensações que evocam, marcam, suscitam a possibilidade de narrativas estilhaçadas em quadros, imagens. Mais de uma vez parece haver uma tensão entre o diário e a memória, como se o diário tivesse sido revisto ou reescrito². Curiosamente, nos anos I920, ele substitui sua voz por cartas, na sua grande totalidade de $G$, possivelmente sua prima Maria Eugênia, que tinha o apelido de Genoca. "Se querem um prefácio, aí está ele. Poderia esmiuçar mais - muito mais, não fosse a experiência posterior do veneno daquele tempo que extravasa-me ainda hoje. Terão assim conhecimento dele aos poucos e com o correr do tempo - só vejo vantagens" (PEIXOTO, I933)3.

Assim voltamos ao que acontece quando o grão não morre, para usar o nome do livro de memórias de André Gide (I982), e se distancia dos medos da infância, dessa infância entre o afeto da avó paterna e as sombras de uma família reservada, nos gestos e na demonstração de afeto, marcada pelas sombras de um passado fausto pelo lado materno, os Breves, e pela riqueza dos Peixoto. Diário e memória parecem se misturar em anotações sem data. Ãs vezes, aparece a idade que Mário Peixoto tinha. Logo uma frase chama atenção: "Num quarto escuro, no meio de brinquedos, crianças brincam coisas inconfessáveis. - Nós somos todos pequeninos monstros" (PEIXOTO, I933). Quais são as brincadeiras inconfessáveis? O que são as monstruosidades dessa infância? Se não chega a ser algo celebratório, quase o mesmo termo que Lady Gaga usa para chamar seus fãs, no diário de Mário Peixoto ele está longe do traço negativo que a associação com a monstruosidade poderia evocar em sujeitos queer antes da revolução sexual dos anos I960. Não se trata de pensar uma "criança viada"4, embora

2 Só tivemos acesso a uma versão datilografada dos Cadernos verdes até agora.

3 Atualizamos a ortografia e a pontuação.

4 Termo de uma série de pinturas de Bia Leite que motivaram grande polêmica e o encerramento da exposição “Queermuseu - cartografias da diferença na arte brasileira” no Santander Cultural de Porto Alegre, em $20 I 7$. 
as ambivalências sexuais de Mário façam parte do mal-estar diante da família em que crescerá até seu definitivo afastamento após a morte de sua avó paterna e de seu pai no fim dos anos 1930.

Do dia em que "G" e eu, segurando um em cada ponta do barbante, estrangulamos um filhote de rola, para sentirmos a agonia juntinho aos dedos. Ia ser mesmo com a mão, mas a escolha do algoz repugnou-nos. Praticamos o ato alucinadamente, olhando para os lados, a tremer por dentro - mas sem por onde escapar -, como que obrigados. (Devíamos beirar os II anos ${ }^{6}$ - e numa tarde em que partia-se de Santa Cecília ${ }^{7}$ para o Rio). (PEIXOTO, I933).

Essa cena, que mostra o compartilhamento de um ato de crueldade infantil associado a uma brincadeira recorrente, marca, por exemplo, a amizade de dois meninos em Vista do Rio (2004, p. I2), de Rodrigo Lacerda, quando colocam um beija-flor vivo num liquidificador.

"Verdadeira exaltação aos $12^{8}$ por pessoa de mais de trinta. Coordenação de ritmos que descobre-se anos após ser nem mais nem menos que amor! Amor inconsciente se quiserem - amorfo ainda na sua concepção, mas não menos intenso e perdurador" (PEIXOTO, I933). Marcaria essa cena a descoberta do desejo ou o reconhecimento tardio de um sentimento passado, mas que joga suas sombras no presente? Que "pessoa" seria essa? A indeterminação de gênero seria para esconder um homem através de uma figura enevoada no passado, sem rosto, sem nome, só com a idade? Aos I2 anos, em Mário o desejo aflora na escrita, reafirmando a existência de uma sexualidade infantil, como afirmava Freud no início do século passado, sexualidade essa diferente da sexualidade adulta, mas completamente afastada de discursos conservadores que só veem a criança como vítima e alvo de sedução. Em parte posterior do diário, Mário anota: "O dia em que acompanhei [foi riscado o termo refiz] solitário todas as marcas que os saltos de 'N’ imprimiram no jardim de casa em Petrópolis. (Poderei definir o impulso como amoroso? É difícil...) 'N' chegara de repente com meus tios; - de carro ou de táxi?” (PEIXOTO, I933). Como o rosto sem nome, aqui a atração é por um corpo sintetizado por saltos, recurso que apareceria no seu filme Limite como indício de uma pessoa e/ou fetiche ${ }^{\mathrm{I}}$ ? Ao riscar a palavra refiz, ele seguiria simplesmente os passos de $N$ ou também a estaria imitando?

5 G seria a prima Genoca ou um primo?

61919.

7 Em Volta Redonda.

81920.

9 Seria uma prima chamada Cornélia, que Mário chamava de Nella?

Io É sabido que Mário gostou muito de sapatos por toda a sua vida. 
Aos oito ou nove, acometido de estados como esses: [...] Você compreende tão bem... tenho receio que algum dia não venham a chamá-lo de original, maníaco... (pausa, depois com ânimo:) Eu sinto - Uma caixinha, um livro ou a minha escova que não fique numa certa posição simétrica ou mais ou menos de acordo com o que agrada aos meus olhos e a mim; um centímetro que o objeto se afaste do ideal pode trazer-me consequências más... azar; o que eu espero não se realizará; no dia seguinte só aborrecimentos, vou ficar doente... Vou morrer... Quem sabe? ... chego a contar... um - dois - três - ... se não fizer no prazo - morro... chego a sentir a vertigem, a falta de ar..... Sustenho a respiração o mais que posso... depressa! E arranjo sofregamente o objeto... o coração a pular-me no peito, o suor frio, a cabeça a latejar-me com um martelo a bater-me por dentro... (PEIXOTO, I933).

Quem seria o "você” a que ele se dirige? Ao diário? A um amigo imaginado, futuro leitor? Já desde bem cedo, um traço de sua personalidade parece emergir, obsessão pela perfeição nas menores coisas do cotidiano e uma devastadora sensação que atinge seu corpo diante de sua impossibilidade. Imaginemos como deveria ser perturbadora a realização de uma obra de arte na juventude em que se soma a autocobrança, como veremos, à vergonha e à timidez:

De um batizado que fui aos treze anos, retenho apenas isso: de volta da igreja, serviram "sonhos" na sala. De uma peça contígua ouvi uma voz de mulher (creio que tia "L") que dizia: - "C”, você quer sonhar? Hoje em dia, ocasiões há em que esse estribilho soa-me sem mais nem menos com o timbre e a ferocidade de um grito lancinante. (Refiro-me ao poder nevrótico e não diretamente ao vocal). No entanto o acento [riscado; tom] fora apenas irônico na ocasião, apesar de um tom [riscado: acento] fanhoso (se não me engano). (PEIXOTO, I933).

Entre a igreja e a casa, chama a atenção, como uma memória sensorial em que o doce sonho se mistura à importância da imaginação, sua indissociabilidade da realidade no que tem de fascinante e dolorosa (im)possibilidade que se impõe a Mário no decorrer do tempo.

Aquela tarde em que cheguei do colégio, o mar estava de ressaca. Viera pela praia e em casa só havia Anna, Zézé e “G”. Fui direto ao salão de visitas, quase sempre escuro e situado na frente da casa de onde se ouvia o quebrar [riscado: ronco] longínquo das ondas. $\mathrm{O}$ baseamento do prédio estremecia lugubremente, estalando portas e janelas a cada investida da água sobre o cais. Enquanto a casa próxima ao mar ecoando uma lenta e constante destruição que obviamente não é só física. Na penumbra, icei-me ligeiramente nas pontas dos pés, para espiar a rua pela vidraça. (O que eu quero precisar é a impressão [riscado: seguinte] que se segue): - "Achei o vidro alto e a rua uma coisa pesada e cinzenta. O enorme tapete da sala jazia enrolado [riscado: aos pés do espelho] com pimentas-do-reino dentro, aos pés do espelho. Saí assustadamente da sala, evitando, sozinho, aquela vasta superfície emoldurada que eu esquecera de repente. (PEIXOTO, I933). 
Tanto a casa como a rua parecem ser lugares lúgubres e assustadores. Se num primeiro momento poderíamos pensar nos clichês de novelas góticas, de filmes de terror, também aqui se dialoga com as casas silenciosas de famílias decadentes de tantos romances brasileiros. Curiosamente, o mar também faz parte do processo de destruição da casa.

Impressões da Santa Casa - Pavor dos cheiros locais (nunca me esqueci!) - Hospital São Zacarias, com a revolta íntima das instâncias da tia "S" para que mamãe não fizesse caso em "repugnâncias de criança luxenta”. Assisti à morte de um menino, no qual fizeram uma trepanação.

Vejo ainda a pobre cabeça mutilada, envolta em gazes, com aquele olhar vago de submissão. Quando me explicaram no que consistia a intervenção, senti náuseas, temendo ver o crânio abrir-se a todo o instante com algum movimento mais brusco do paciente.

Tia "S" sorria - para encorajar naturalmente. Levou-me para ver os quadros de gesso com motivos religiosos, que ela fazia com as sobras das formas de fraturas e paralisias.... Sobre a cama do moribundo eu notara uma das tais imagens.

Tenho culpa de odiar hoje em dia essa tia "S"? Que querem; instintivamente é o bastante falarem nela para sentir repulsa e “o forte cheiro de iodofórmio!”. (PEIXOTO, I933).

Diante desse ambiente lúgubre, não parece surpreendente que, depois da casa ameaçada pelo mar, da rua cinzenta, curiosamente, o primeiro espaço longe dessa cena que aparece com destaque é a Santa Casa, à qual Mário é levado por uma tia para assistir à morte de um menino. $\mathrm{O}$ hospital é encenado pelos cheiros que se misturam na lembrança ao cheiro da própria tia. Passeio curioso de uma tia fazer com um sobrinho, supostamente, para que a criança não ficasse dengosa, no limiar, para construir um homem forte capaz de lidar não só com a morte, mas com sangue, sofrimento e dor, cena ainda mais impressionante quando se trata de uma criança presenciando a morte de outra. Ou ainda uma hipersensibilidade que procura um refúgio, um esconderijo. No lugar de um armário, um baú. "O dia em que chorei no corredor, sem motivo definível, estendido de bruços sobre a arca preta do "n. 26 " [da rua Almirante Tamandaré]. Depois parei, achando a arca do meu tamanho, e que caberia bem lá dentro. Isto consolou-me" (PEIXOTO, I933).

Curiosamente não são os pais, o irmão, os avós que primeiro aparecem na cena do diário, mas três parentas idosas, possivelmente primas, que exercem em Mário um curioso jogo de fascínio e repulsa quando ele as visita. Elas parecem, ao mesmo tempo, figuras do passado, como se ele entrasse num mausoléu repleto de relíquias em que quase se misturasse a elas e olhasse para um possível futuro, como vemos pelo destino de Rosa, com quem brincava na infância. Elas ajudam Mário a se compreender como um espelho antecipador do que ele poderia ser..... Como no fragmento abaixo, sem data nem referência de idade, que parece ser posterior à infância, mas já seria nos anos I920, já que os casamentos aconteciam relativamente cedo. Solteirões e solteironas, três tias que viraram religiosas, mais tio Humberto, que morrera jovem de tifo e com quem Mário tinha um vínculo afetivo (PEIXOTO, I933), e sobre quem a família se calava (CASTRO, 2000, p. 27). Haveria entre esses e 
Mário alguma afinidade mesmo que fosse para reconhecer do que tentaria fugir e o que poderia lhe ser reservado?

A casa das primas “B”. (O mundo que ela evoca). Três parentas idosas, preservadas cada uma num dos três confortáveis andares evocando à cânfora.

Um silêncio carinhoso, egoístico de fragilidade, que faz a gente perdoar tanta coisa a si mesmo?! Quase compreender-se!

Rosa [riscado: uma rapariga], protegida da casa. Aquela mesma com quem brinquei de teatro com cenários de Jornal do Comércio. A mesma ainda que se casou, teve filhos e, numa das últimas vezes que lá estive, soube viver ainda a mesma vida de "forma", e inevitável, que eu instintivamente lhe previra (querem saber que eu já me esqueci da sua fisionomia?).

... Refastelava-me n'uma [riscado: numa] d'daquelas “bonachonas” cadeiras de braço do salão de visitas, com aquele cheiro de luxo descorado, e sempre o mesmo.

... A senhora chegou-se vindo do fundo da peça, com o froufrou do tafetá rodado e o blusão branco com rendas verdadeiras.

"Disse-me que em menina brincava com bonecas naquele óculo da escada".

Havia também a estatueta de sáxeo sobre o aparador de mármore (ao lado do relógio com o pêndulo cilíndrico de ouro) com a qual sempre troquei um olhar mais íntimo como quem se reconhece. (Guardo a sensação, não a estatueta.)

Uma sensibilidade extrema me impedia às vezes de olhar para ela; parecia-me que ia compreender tudo tão profundamente da minha cadeira que poderia tornar-se de repente a coisa mais extraordinária do mundo. Interessava-me então pelo camafeu antigo preso à gravata de rendas da minha parenta.

- Que bonito broche, prima "L"!

Ouvia-se espaçadamente um bonde na praia; não me lembro nunca de ter visto alguma delas chegar à vidraça e afastar uma cortina para vê-lo.

(Falar no oratório - armário embutido na parede do quarto de vestir de prima "L"). (PEIXOTO, I933).

O pai de Mário, João Cornélio Rodrigues Peixoto, não aparece na infância. Ele nunca teve um trabalho do qual pudesse viver e isso era mais um motivo para despertar a raiva que seu pai sentia, além de ter se casado contra a sua vontade com Carmen de Souza Breves ${ }^{\text {II }}$. Mesmo quando moravam na mesma casa, José Rodrigues Peixoto, pai de João Cornélio, e Carmen não se falavam. Um pouco da raiva do avô para o filho passou para o neto Mário, chamado por ele de intruso. $O$ furioso avô nos faz lembrar Lucas Procópio, protagonista do romance homônimo de Autran Dourado (I985). João Cornélio trabalhou no Jardim Botânico, possivelmente devido a sua formação quando jovem na Bélgica (RESENDE, I997), tendo deixado um diário que ficou com Wilma Ferreira Alves Peixoto (PEIXOTO, I998), mulher de Octavio, irmão de Mário. De acordo com Alcides da Rocha Miranda, amigo de infância de Mário, João Cornélio era "um homem muito... muito retraído, falava muito pouco. Muito

II Há mesmo uma história de que os pais de Mário teriam fugido para o Rio de Janeiro e depois para a Europa para se casarem (MONTEIRO, I972). 
firme, muito civilizado" (MIRANDA, I996). Elegante, calado, reservado, qualidades que pareciam pesar sobre os Peixotos e também sobre o filho de Lucas Procópio, João Capistrano, protagonista de Um cavalheiro de antigamente (I992). A última herdeira da família Honório Cota mora só no sobrado da família na obra-prima Ópera dos mortos (I967). Mário Peixoto tenta romper de certa maneira esse trajeto de exclusão, solidão ou loucura em que os herdeiros que fogem aos parâmetros hetenormativos costumavam ser marcados. Tendo Carmen morrido cedo, em I922, foi o pai que o levou a conhecer a Europa, mas talvez desde cedo a sensibilidade e a delicadeza de Mário o exasperassem. Segundo Mário, por volta de I929-I930 brigaram em Paris por conta da presença de uma amante do pai. Após o incentivo para que Mário publicasse seu livro de poemas Mundéu em I93I, reeditado só em I996, com apoio de Manuel Bandeira, amigo de João Cornélio, ele teria queimado os exemplares de $O$ inútil de cada um em I935, reeditadp em versão ampliada em I984, por considerá-lo escandaloso para a família, fato que não é evidente, havendo versões diferentes tanto sobre o motivo da destruição dos exemplares quanto ao seu caráter escandaloso, quando da reedição dessa primeira edição pela Editora 7Letras em I996. Não encontramos, numa primeira leitura, razão para considerá-lo como tal, opinião compartilhada por Almir de Castro (CASTRO, I988). De todo modo, após a morte de sua mãe, Cornélia, em I936, João Cornélio passa a morar só numa humilde pensão, em tudo oposto ao caráter perdulário do filho. Ele morre em I939 de câncer ou tuberculose. A grande figura masculina do diário é o avô paterno, já que o avô materno, Joaquim José de Sousa Breves Filho faleceu em I9I2, quando Mário tinha só quatro anos. O avô não é nomeado por Mário, chamado ironicamente de vovô. José Rodrigues Peixoto, médico, era casado com a muito adorada avó Cornélia, sentimento quase oposto ao que Mário sentia pelo avô. Há uma dificuldade de encontrar outros depoimentos sobre a infância de Mário, uma menção aparece no depoimento de Antonio da Nova Monteiro, que só o conheceu em I938. No início se recusou a falar da família e da infância de Mário Peixoto, que diz conhecer, mas deixou transparecer e depois afirmou com clareza que "existiram sérios traumatismos de origem familiar na infância de Mário” (MONTEIRO, I972)

Portanto é nessa casa que se inicia o longo e gradual afastamento da família, ainda mais marcado pelas mortes de sua avó Cornélia em I936 e de seu pai em I939. Parece que houve tentativas por parte das primas (Justina, Cornélia) de se aproximar de Mário, mas a intimidade da juventude tinha se perdido. Mário era outro. Não era possível voltar atrás. Não foi um gesto como a fuga de André em Crônica da casa assassinada (I958) de Lúcio Cardoso, após o velório de sua mãe. Um longo adeus erguido da infância até a juventude. Um adeus de que não houve volta. A casa de seus avós, de seus pais, ficará lá perdida no tempo, sendo enterrada pouco a pouco. "A casa de que eu preciso fugir. (Lá em casa!) Poeira... Ela pode mais que eu - governa todos (ninguém percebe) como que olhando-nos de cima para baixo" (PEIXOTO, I933). Houve fugas, como o cinema, por exemplo, que já apontavam para outros mundos, outros destinos. 
Agora um segredo. Sabiam que quando tio "F" $F$ faleceu, na noite ainda que se seguiu ao enterro, eu fui ao cinema? Deixei a família em concílio de lágrimas e escapei-me inesperadamente, com a roupa que estava - Surpresa para mim próprio. Não pensem que é falta de sentimento! Meu Deus, apenas por aquela "quebra” de cerco imaginário! Mas ninguém via, então?! (PEIXOTO, I933).

Então Mário sabia do que fugia, mas não o que procurava. Anos depois, após estudar na Inglaterra e ir a Paris, voltou para Mangaratiba, cidade onde seus antepassados viveram, mas seu encontro é menos por isso e mais pela força do mar e da natureza, de pessoas da região com quem pudesse se sentir mais à vontade. Suas fantasias foram para as leituras, para a escrita, para os quartos de hotel e passeios pela praia. Quando o sonho de uma casa-museu na Ilha do Morcego se desfez, só lhe restou um humilde quarto num humilde hotel em Angra dos Reis. "Quando ando tolamente e volto ao mesmo lugar com um conhecimento trágico do meu caráter" (PEIXOTO, I933). Assim terminam os fragmentos sem data e, como apresentação ao ano de I92I e ao conteúdo do diário, Mário escreve:

São as reprises íntimas da minha tela-portátil.

O repasto é dos de primeira, apesar do escândalo e dos leves toques de carniça - [riscado: ainda] vão ver....

Para um documento único desses é inestimável; o possível desengano que me aguarde num sentido (o que temo só as vezes, para reerguer-me em seguida) não tendo tempo de alcançar-me com a "intrusa".

Por isso vai assim mesmo.

Podem banquetear-se:

(PEIXOTO, I933).

Nessa segunda parte, saem de foco as confissões, as imagens pesadas da infância, e aparecem as cartas de suas primas, em especial, da prima $G$ (Genoca?), além de Cornélia, Vera, Olga e Cecília. Forma de falar de si a partir do outro? As cartas encobrem o peso da família e lhe abrem não uma porta, mas pelo menos uma janela para festas, do Carnaval, por exemplo, entre o Rio de Janeiro e Petrópolis, de uma intimidade mais leve e leviana, quando Mário Peixoto tinha I3 anos e estava em alguma fazenda, enquanto sua prima Genoca estava no Rio de Janeiro. Em sua biografia há referências a viagens pelo Brasil (CASTRO, 2000, p. 35), mas não há referência a essas viagens em seu diário. Alcides Rocha Miranda (I909-200I), amigo de Mário, menciona a Praça do Alfonso, o Tennis Club, a Confeitaria Falcone, o café D’Ângelo, lembrando-se mais do cinema do Centro Católico do que do Cine Capitólio ou do Cine Petrópolis como lugares de encontros, além das casas uns dos outros (MIRANDA, I997). Na carta de 2I/2/I92I, Genoca fala de brincadeiras, fala dos preparativos para o Carnaval e de uma festa aquática. Em nota colocada por Mário, entende-se o grau de intimidade entre os dois ao dizer que quem escrevia as cartas de namoro de $G$ era ele, Mário.

I2 Flávio Rodrigues Peixoto. 
Já escolheste fantasia para o carnaval? Ontem realizou-se uma grande batalha de confete na rua Copacabana, estava estupenda! Uma banda de música "tremelicada" que quando tocava parecia gatos miando, meia dúzia de cordões, uma dúzia de mascarados negros que pareciam formigas. Enfim, o carnaval dos subúrbios é melhor que este de Copacabana. No domingo realizou-se uma grande festa aquática, no páreo de papai entraram 4 meninos e mais o “B”; este apenas deu quatro braçadas e parou. Quando vi que o "B" tinha dado o "prego" passei a mão na toalha de banho, pus o rabo entre as pernas e saí correndo como um cachorro danado. O resto fica para a próxima carta. Lembranças a teus pais, tios e avós. Receba um afetuoso abraço da prima e amiga "G". (PEIXOTO, I933).

Logo depois há uma carta sem data em que $G$ continua a falar propriamente do Carnaval e de ter conhecido a vencedora de um concurso de beleza enquanto Mário parece ainda estar numa fazenda. Seria a que foi anunciada na anterior? Não mais o peso da descrição de Mário de sua casa ou da cidade. Sua prima parece tão solar quanto ele, soturno.

Divertiu-se muito no carnaval? Aqui esteve muito bom! No domingo de manhã houve banho à fantasia. À tarde fizemos corso fantasiadas de "confete-americano". No segundo dia fui fantasiada de "Alsaciana", no terceiro de novo de "confete-americano". Apenas demos uma volta fazendo corso, quando caiu uma forte pancada de chuva. Fomos então obrigados a encostar o automóvel num recanto, para nos abrigar e ao mesmo tempo para tomar lugar a fim de vermos os "carros alegóricos". As 8 1⁄2 passaram os "Fenianos", cujos carros estavam riquíssimos. A I hora da madrugada passaram os "Tenentes" e os "Democratas", este último estava um assombro, nem posso te explicar como, só te digo que estava uma maravilha. Depois de passarem os carros, continuamos o corso o qual está concorridíssimo. Já te mostrei a minha impressão sobre o esplêndido carnaval. [...]. Não imaginas Mario, ontem tive ocasião de ver a Martha Rosas. Não calculas como ela é feia, pequena, franzina, angulosa, com as costas levemente arqueadas como a das tartarugas. É uma dessas criaturinhas frágeis, leves, que lembram as franguinhas depenadas. Quando nos domingos ela faz "footing” com o seu vestido de organdi roxo, a impressão que se tem é que o vestido anda sozinho arrastado na rua pelo vento ( $\left.{ }^{* * * *}\right)$. Tinha bastante curiosidade em conhecê-la; pois agora só estou ansiosa para que você a conheça também e terás a mesma impressão que eu. Lembranças a vovó, vovô e todos os meus tios e primos. Receba um abraço cheio de saudades da prima e amiga que te lembra a todo o instante "G".

P.S. manda-me dizer se vovó recebeu uma carta minha

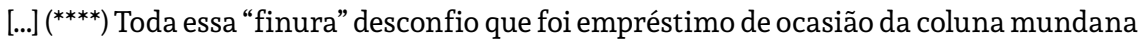
de um "Fonfon" ou "Careta" qualquer, segundo "G" mesmo deixou transparecer em conversa posterior. (PEIXOTO, I933).

O interesse por roupas e detalhes transparece em carta posterior, novamente sem data. De fato, ele parecia ser bem acolhido e ter mais afinidades com a prima, como demonstram as brincadeiras que ela faz e as palavras afetuosas que dirige a ele. A festa parece continuar ou é o que interessa à prima contar a Mário, pois $G$ diz 
que ele "colecionava” amigos, e Mário destaca esta frase. Curiosamente ainda não temos nenhuma informação sobre a presença de Mário nas festas. Seria porque ele frequentava pouco ou, obviamente, as cartas de $G$ só aconteciam quando ele estava fora do Rio de Janeiro?

\section{Querido primo}

Recebi a sua cartinha que me deu grande prazer. Mandaste descrever a tal fantasia de "confete-americano" pois lá vai: - Começa por uma saia de setineta amarela, cheia de bicos embaixo. Um cinto ornado de violetas, um chapéu em feitio de pacote de bombons com um bruto penacho da mesma fazenda, e no começo do penacho um ramo de violetas preso por uma fita roxa. Uma fita amarela com umas violetas no pulso. Lábios, face, olhos, sobrancelhas, tudo pintado. Eis aí a fantasia. Aqui tem chovido horrivelmente, mas nem por isso perco os banhos, que têm estado uma maravilha. Imagine você que ontem foi a primeira vez que dancei depois que cheguei da fazenda. Pois estava tão "peada”, que depois de dançar três vezes não aguentei mais; fui obrigada a sentar, e também suava tanto que, se torcesse as roupas, encheria uma bacia, como diz a "L".

Mário, teria muito prazer em ser apresentada a essa tal vaca "Pororoca”, pois estou vendo que na roça só arranjas amiguinhos "quadrúpedes”. Precisas arranjar também "bípedes" para completar a coleção $\left(^{*}\right)$. Aqui no meu recanto só arranjo "aquáticos" como sabes, por isso não preciso citar os nomes. [...]. Não me mandaste dizer como vai o tocador de violão ${ }^{\mathrm{I} 3}$. Já voltou para a fazenda? E o Thebas “mandão reformado", já fez nova visita? Com a sua magnífica calça de linho pardo $\left({ }^{* *}\right)$, mas coitada... com a janela aberta. Fecha a janela dele, Mário, que aí vem chuva!

Lembranças a todos. Receba um afetuoso abraço da sua prima $\mathrm{m}^{\text {to }}$ sapeca " $G$ ".

$\left({ }^{*}\right)$ - Interessante como essa frase pode revestir-se de uma observação e de um sentido maior.

$\left.{ }^{(* *}\right)$ - [riscado: O cavalheiro] filho de fazendeiros vizinhos que visitara nossos avós com umas célebres calças de fundilhos rasgados. (PEIXOTO, I933).

Em I922, quando Mário tinha I4 anos, as cartas de $G$ continuaram. Tudo parece dizer respeito ao universo dos conhecidos. Nenhuma referência a fatos históricos, políticos ou sociais. A morte de Carmen, mãe de Mário, também não é mencionada. $G$ e as irmãs visitam Mário na casa da vovó Cornélia aos sábados. Um primeiro bilhete de $G$ enfatiza a relação entre os dois, marcada pela alegria, pelo prazer: "Estou ansiosa para estar contigo, pois preciso muito rir rir rir... não faço outra coisa o dia inteiro que chorar e viver triste, com todos e com tudo. Muitas saudades da sua prima muito amiga, 'G’”. Num terceiro bilhete de G, também sem data, aparece pela primeira vez a presença de Mário em festas:

I3 É a segunda vez que $G$ se refere a um tocador de violão sem nomeá-lo. 
Estive ontem com a "MK", que me disse que há por esses dias uma grande festa em casa da “M”. Já sei que estás convidado para uma festa. Hum, que importância!!! Divirta-se bastante. Fui a um chá-dançante segunda-feira; estava de qualidade. Quando é que apareces lá em casa? Estou te esperando para dançarmos a valer. (PEIXOTO, I933).

Já em I923, há duas cartas de $G$ para Mário, vindas de Petrópolis, cidade de descanso desde o período monarquista e onde havia muitas festas e intensa vida cultural, como testemunha $G$ em carta de I7 de setembro, bem como aparece um gosto compartilhado pelo cinema:

Tenho gostado imensamente de Petrópolis. Acho isto aqui um paraíso.

Saio quase todos os dias, e nos domingos pode-se dizer que só ponho o pé em casa para dormir. Para veres como não é mentira, vou te contar todas as minhas diversões de domingo passado.

Domingo: Acordei eram 8 1/2, vesti-me para esperar o trem das Io na estação, em seguida fui à missa das IIh no Sagrado Coração ("missa chic"), depois fui almoçar no hotel Max Meyer em frente à estação, quando acabei de almoçar eram 3 horas, dei um passeio até a Cremerie de automóvel. Em seguida "C" e "O" foram tomar banho na piscina do Shuback perto da Cascatinha e eu fui para o Tennis Club, pois todos os domingos tem "chá dançante”. Dancei sem limite. Eram 7 horas quando saí do Tennis, fui para a praça D. Affonso encontrar-me com "C" e "O", vim para casa jantei às fúrias, indo em seguida para a estação levar uma amiguinha que ia pelo trem das 8 e 35. Depois da estação fui para o cinema assistir “A mocidade precisa amar”! O cinema estava repleto. Saí deste às II $1 \frac{1}{2}$ da noite voltando em seguida para casa morta de cansaço.

O pessoal como vai? Ainda sonhas com o cinema? Tenho me encontrado com todas as colegas e professoras do colégio.

Jantei 3 vezes no Palace-Hotel de Petrópolis, e aí me encontrei com “LRB”, minha grande amiga.

Segunda-feira vou estrear o $I^{\circ}$ banho na piscina. Que sonho!

Esta é colossal e tem todas as espécies de divertimentos que podes imaginar. Tem uma bruta cachoeira onde as pessoas se lavam depois do banho. Toda a alta sociedade de Petrópolis vai assistir. Outro dia levei Titia “S”, esta ficou tão entusiasmada que quase se atirou vestida.

Receba um saudoso abraço da sua prima e amiga

“G”. (PEIXOTO, I933).

A segunda carta de Petrópolis é data de Io de fevereiro de I925, novamente próximo ao Carnaval.

Mário! (Meu primeiro sem segundo)

Recebi sua carta, que mais uma vez revelou-me o entusiasmo louco que está por Copacabana. Será possível que o teu pescoço engordou a ponto dos colarinhos não servirem? Francamente acho um pouco de exagero. Não compreendi um trecho de sua carta em que falavas da lancha do "G" e do "J" ao mesmo tempo. Peço-te encarecidamente 
que me escrevas umas cartas menos aluadas, pois, falando com sinceridade, estás fazendo papel de caipira que nunca viu o Rio de Janeiro, principalmente o mar.

Que tal a batalha de confete que devia se realizar no domingo passado? Já foste aos cinemas daí? Que tal achaste? Todos aqui estão muito saudosos de ti... principalmente titio "JC"I4, vovó... eu também. Passei o dia de domingo com "MB", "MC" e "ML”, vêm quase todas as tardes andar de bicicleta aqui em casa. Já tiveste ocasião de conhecer a “AC”? Lembras-te dos trotes? Logo que cheguei aqui, levei um formidável e, como ainda não estou bem prática nesse negócio, caí como um patinho.

Então, já fizeste o footing com a "C”? A sua bicicleta está com o pneumático furado, assim diz a "F”, porém, isto é fácil de se arranjar. Estou à sua espera para começarmos a fazer grandes passeios... de bicicleta.

Adeus. Saudades aos titios. Receba um abraço cheio de saudades da prima, amiga fiel e confidente

Muriac Ocnia.

P.S. Era como eu escrevia o meu nome antigamente. (PEIXOTO, I933).

Há uma carta de $N$ (a governanta mencionada mais à frente que recebeu carta de Mário?), pouco antes de Mário ir para Inglaterra, para enquadrá-lo nas expectativas que a família parecia ter com sua viagem quanto a arrumar namorada e manter-se religioso.

Aqui começam as cartas durante a viagem de Mário à Inglaterra. Em carta datada como Rio, 9 de setembro de I926, que assina $N$ - que poderia ser a avó Cornélia, embora só tenhamos a referência do apelido Nella para a prima Cornélia -, o tom é de uma pessoa mais velha fazendo recomendações dentro dos valores da moral da época, da religião e da heternormatividade, bem como alimentando suas fantasias em ser ator de cinema.

Meu ilustre secretário!!! (*)

Envio-te com um grande abraço estas flores, que têm por fim fazer-te companhia, em meu nome, durante [riscado: a viagem] um bom trajeto da tua viagem, e levar-te os melhores votos de felicidade, a fim de que tudo te corra às mil maravilhas!!!...

É uma insignificante lembrança, mas, contudo, espero que elas te digam quanto esta tua pobre amiga te quer, dando, portanto, a elas, o valor que merecem, pois o que vale aí é a intenção.

Não esqueça de nós no meio de tanta balbúrdia.

Espero que nos escrevas sempre, dando sempre notícias do que tens feito. Não vá esquecer de mandar o teu novo "adress".

Pode ser que daqui a dois anos, quando pretendes voltar, encontres tudo modificado, até as tuas primas (o que tenho poucas esperanças), mas, para Deus, nada é impossível e, portanto, vejamos!...

Não sei o que será de ti durante esse tempo.

I4 João Cornélio.

I5 Maria Luiza Sertório. 
O meu desejo é que voltes um perfeito "gentleman", de ombros largos, falando corretamente o inglês, e tudo o mais, enfim, mesmo com duas "girls", uma em cada braço, mas, por favor, não venha com a moral corrompida!

Quem sabe, brevemente receberei notícias de que mais um "astro" entrou para a "tela" e venhas a ser o substituto de Rodolfo Valentino, o novo herói da cena???!...

Adeus, camarada, nada disso me surpreenderá, pois tudo na vida é natural, só que nunca abandones a tua religião e não te esqueças nunca de mim. Um muito apertado abraço, o último adeus da “N”6.

$\left(^{*}\right)$ - Carta encontrada dentro de caixa, sobre ramo de violetas, endereçada a $\mathrm{Il}^{\mathrm{mo}}$ etc. “Camarote 687 Paquete Andes”.

Bisada (sic) em cima, na Ia. página, a palavra “Saudades” em grande. (PEIXOTO, I933).

Depois, a rotina das cartas de $G$ volta, com notícias da família, de festas, e a informação de que Mário não está gostando do Hopedene College.

\section{Rio 8-II-I926}

Querido Maroquinhas,

Recebi o teu amável cartãozinho da ilha da Madeira. Não respondi logo, porque ando $\mathrm{m}$ o malandra e também meio adoentada. O menor esforço que faço, fico exausta e tenho sempre vontade de me deitar.

É sempre com vivas saudades que me lembro de ti e das nossas camaradagens. Já soube por carta escrita a vovó que te sentes $\mathrm{m}^{\text {to }}$ isolado e saudoso naquele pequeno recanto, aliás pitoresco da Inglaterra.

$\mathrm{Li}$ a sua primeira carta dirigida à mesma, e achei $\mathrm{m}^{\text {to }}$ interessante as suas impressões da Inglaterra. Creio que o que mais te agradou até agora foi a viagem. Não?

Então, o seu smoking fez $\mathrm{m}^{\text {to }}$ furor, não é verdade? E aquele namoro com uma inglesa velha? Com toda a certeza, deves estar um "batuta" nas declarações em inglês. Que achas? ... dolorosa interrogação!!

Já estamos em pleno verão e Copacabana está simplesmente adorável, quer dizer, banhos animadíssimos, caras e roupas mui to bonitas e praia futurista... compreende? Por aí podes bem afigurar o que seja, e como também já passaste em casa da titia braba (que agora está muito mais mansa) o tempo mais animado desta incomparável praia, naturalmente, lendo estas linhas, ficarás com saudades desta deliciazinha rara.

Atualmente tem havido uma série de chás-dançantes, concertos e festivais artísticos. Temos ido a algumas dessas festas, cujas organizadoras são conhecidas e nos enviam cartões.

A festa das margaridas, realizada logo após a sua partida, esteve excelente. Como era sábado, fomos footingar com vovó na avenida e não escapamos ao "assalto”. "A de P" era uma das "assaltantes". Quando a avistei me lembrei $\mathrm{m}^{\text {to }}$ de ti, e daquela margarida guardada com todo o cuidado, numa caixinha de joias.

Quarta-feira Io do corrente a "L" colhe mais uma rosa no jardim de sua existência. Como é de praxe, esta festejará a sua data natalícia em casa de vovó, que já encomendou

I6 Prima Cornélia? 
uma perna de carneiro do Rio da Prata, pois, aquela assim o exigiu. Se o tempo for favorável irão após o lauto banquete passear em S. Domingos.

A “Z” continua em S. Lourenço fazendo as suas belezas. Há pouco tempo, escreveu a mesma uma carta à titia “J”, pedindo que lhe fizesse um vestido (naturalmente arranjou algum "begin") e quem serviu de manequim foi o pobre do titio "E".

O resto da família continua bem, e sem novidades.

Estou lendo um romance em francês intitulado "Fiancée" cujo autor é Guy Chantepleure ${ }^{\mathrm{I} 7}$. É um mimo de bem escrito, e o desenrolar do mesmo prende cada vez mais a minha atenção. Em inglês estou $\mathrm{m}^{\text {to }}$ "crua". Acredita que ainda não me animei a ler o livro que miss Kehr me deu em Petrópolis? “C” e "V" são atualmente as duas "pipas” da casa, ao contrário de "C", que está um perfeito graveto e ameaçada de ir para o pasto (S. José). Temos agora uma cabra que fornece todos os dias I litro de leite, o qual é tirado exclusivamente para “O”. A mesma já aumentou I quilo com o novo leite, que é $\mathrm{m}^{\text {to }}$ forte e saboroso.

Esquecia-me de te contar que o "C. A." (filho da "V") entrou para a orquestra de "DV". Deu, o mesmo, uma festa em sua casa para a qual foram convidadas, "C" e "V" e as duas "M”. Porém, só as filhas de titia "SD” que foram,

$\mathrm{O}$ "MR" andou com a memória abalada devido aos exames, de maneira que foi fazer uma estação de águas em Caxambu.

Uma colega de "C" contou-lhe que o "JF" está noivo da filha do “CN". Realmente avistei-o há pouco tempo no teatro João Caetano juntamente com uma menina.

É tudo quanto tenho a te dizer.

Escreve-me se puderes.

Aguardo uma cartinha sua contando-me novidades.

Com $\mathrm{m}^{\text {tas }}$ saudades abraça-te a prima $\mathrm{m}^{\text {to }}$ amiga “G”. (PEIXOTO, I933).

Em carta antes do fim de ano, a prima $G$ fala de um pretendente e de novidades da família, de forma informal, mas muito íntima.

Rio 27-I2-I926

Meu querido primo.

Antes de mais nada, venho te desejar "Merry Christmas, and a happy new Year”. Não posso deixar de dizer que já me supunha esquecida, quando recebi o seu amável cartão. Como já deves imaginar, fiquei $\mathrm{m}^{\mathrm{to}}$ contente. Entretanto, não ocultarei o meu desejo de receber, na próxima vez, uma bem longa e noticiosa carta, pois, na qualidade de prima confidente, tenho tanto ou talvez mais direito que "C" e "O".

Que achas da minha pretensão?

Quando esta carta chegar às tuas mãos, já te encontrará informado da paixão que inspirei, sem querer e sem saber. Agora sim, me acho bela, pois, assim diz o ditado: "A pessoa só é realmente bela, quando se acha bela para alguém”.

Ainda não tive ocasião de ser apresentada à minha nova conquista. Entretanto, já o conhecia de vista, isto é, só o vi uma vez, em que saía da casa de "V" em companhia da

I7 Escritora francesa de romances sentimentais que usava um pseudônimo masculino. 
mesma e aquele a cumprimentou. Não o achei bonito. Tem, contudo, uma fisionomia agradável de se olhar.

Meu Deus! Qual será a tua impressão sobre esta xaropada? Dolorosa interrogação!!! “V” partirá brevemente para Petrópolis. Não sei se também irei. Tenho pesar de deixá-la ir só, porém, tenho também vontade de ficar. Estou numa brutal indecisão. Estive há dias com as “ $M$ ”' , que há $\mathrm{m}^{\text {to }}$ não via. Estão cada vez mais pedantes. Já soube por "V" que estão as mesmas proibidas pela Miss Kilo ${ }^{\text {I9 }}$ de responder às tuas cartas. Nunca vi inglesa mais cretina. Papai tomou uma mesa para o reveillon do Jockey, que está sendo esperado com grande ansiedade pela elite carioca.

Como sabes, é o mesmo, o club mais elegante do Rio atualmente. Paga-se de ingresso Io0\#000 cada pessoa, tendo direito ao soupé. As moças ganham prendas no valor de $40 \# 000$ cada uma. O baile vai ser no jardim que estará nesse dia profusamente iluminado. "C" irá com um vestido de lantejoulas doiradas, tendo no corpo de vez em quando, lantejoulas vermelhas, formando dálias e a barra de lantejoulas pretas. Este vestido foi comprado na Marjolaine. O de Olga é cor de champagne. O corpo é liso e justo. A saia é godet com rendas da mesma cor. Este é modelo da Zerbini. "M", que também foi convidada, irá com um vestido de rendas pretas. Finalmente eu entregar-me-ei aos braços de Morfeu, que ainda é melhor que tudo isto.

E aqui fico, meu Maroquinhas, esperando com ansiedade, uma bem longa e noticiosa carta.

Abraça-te com $\mathrm{m}^{\text {to }}$ carinho tua prima confidente "G"

[...]

P.S. Fraulein manda te comunicar que recebeu sua carta e que vai responder.

Transmito também as saudades que “J” te envia. (PEIXOTO, I933).

Na última carta que $G$ manda do Rio de Janeiro para a Inglaterra, temos uma imagem do que se passa com a família e primas. A quantidade de abreviações, segundo $G$ código secreto para falar dos encontros amorosos, às vezes prejudica a compreensão. Paira uma dúvida se a volta antecipada de Mário, antes dos dois anos previstos, só tem a ver com a necessidade de organizar o futuro dele em direção a uma profissão. Diante da polêmica das fotos, parece que Mário inventou uma namorada para se contrapor à fotografia com seus amigos japoneses. Parece que ele não faz confidências amorosas para a prima porque talvez o que sentisse não pudesse falar...

25 de julho de 1927

Mário

Recebi hoje pela manhã a tua carta datada de 6 de julho, e te respondo hoje mesmo, para te mostrar que não sou ingrata e, que nem tampouco preciso dos teus vasos [...] Se soubesse que eram da tua mãe, nunca os teria pedido. Desculpas e obrigada.

Esta é a última que te escrevo e, por isso, faço-o em block, para dar maior intimidade, depois de tanto tempo de ausência. Chegou afinal o dia do teu regresso, é preciso que te armes de coragem para as próximas e futuras confidências...

I8 Maria Eugênia e Maria Luiza?

I9 Miss Kehr? 
Tio “JC" ${ }_{20}$ lá não foi, não vai, nem nunca irá. “C” mandou dizer que ele está muito ocupado com “L”. Parece até outro homem quando esta vai ao 35 (?). Ficam abarracados o tempo todo.... Por isso ele já mandou ordem terminante para a tua volta. Vais ser embarcado a domicílio, como qualquer cachorro danado, no fim de agosto. Somente ele não determinou a data, porque deixou o navio a tua escolha.

Estamos todos radiantes e preparando o enxoval para a tua recepção. Seu pai assim resolveu, porque quer ver de perto os teus progressos. Se na verdade forem vantajosos, te fará voltar mais uma vez, mas não mais para um colégio de garotos, pois já és um homem feito.... Não é???

Ele acha que no inglês já estás batuta. Precisas agora estudar e cavar a vida, isto é, trabalhar.

Eu e a "C" somos da mesma opinião, deves vir, senão nós caímos no mangue por causa das saudades.

Falando sério, achamos que estás perdendo teu tempo. Inglês se aprende num ano, e o resto, tão bem aqui como lá.

Precisas vir para começar a trabalhar, senão será tarde, e só você terá um dia que sofrer as consequências, ou então, fazer sofrer alguém, como aconteceu conosco, por falta de arame. Não achas? És brasileiro, portanto, deves vir para o Brasil, para o seio da tua família, senão acostumas com a vida inglesa, e depois farás como a "O”. Ainda conversando sobre ti na lição de inglês, Miss Kehr disse-nos que seu pai faz bem em mandar-te vir embora, não só pelas mesmas razões, mas ainda por estares na idade perigosa (a idade of love making), pois, diz ela, as inglesas são muito traiçoeiras. Podes te apaixonar por alguma inglesa e depois vai ser um buraco! Estrangeiros casados nunca dão certo! Bem o sabes.

Ainda mais, diz a miss Kehr que as inglesas são terríveis e muito espertas, aproveitam a ingenuidade dos de fora, fazem com que vocês se comprometam com elas, mediante promessas, cartas, anéis etc. e depois vocês têm que casar, ou pagar uma grande soma se os pais tiverem fortuna, pois a lei lá é muito severa, e os flirts acabam sempre no tribunal da justiça. Estou te dando este aviso por causa da tua (tabaconist-girl). Não lhe digas nada, mas acho que deves restituir-lhe a fotografia antes de vires, quem sabe ela está te armando alguma??

Tens razão, aventuras não se contam em cartas, quero ouvi-las pessoalmente, A encrenca da sua pose de bailarina já foi esquecida. "V" já recebeu os retratos com o grupo do colégio.

Parece de propósito, tudo chega no sábado e, assim nós também vimos e gostamos. Mas achamos todos pavorosos, menos você. No retrato trepado na árvore, estás bem mais liso e gordo, que sonho terem desaparecido as tuas espinhas; só sinto não poder recorrer ao mesmo remédio eficaz...

A “C” não te escreveu por simples descuido, quando se liga, não se é ligado, é sempre assim.

Ela respondeu as tuas três últimas cartas, uma bem noticiosa, e mandou-te algumas revistas.

Traga as tais revistas francesas, devem ser excelentes. 
Como vais te arranjar aqui sem a tua (tabaconist-girl)? Quem será a sucessora? Vais cair no ....? Ou continuarás como antigamente? Olha que o "B” e o “B. estão se preparando para te fazer um exame em regra. Olha lá se não passas com distinção!

A numeração $\left(^{*}\right)$ está na mesma. "C" há 2 meses que não fala com o "M" e há mais de I mês que não vê o " $R$ ”, o qual desapareceu numa onda de mistério. Não se sabe por enquanto se ele morreu ou caiu na farra. Até de casa mudou e ao trabalho não vai mais. Agradeço os teus pêsames pela morte de minha "S". O meu número continua na mesma. Não canso de esperar... porque nunca esperei, nem espero nada, apenas o fim do mundo. Tenho medo de que esta carta aí não te encontre mais, por isso não serei extensa.

Eu também sinto saudade da nossa camaradagem, e só sinto que também não tenhas aumentado o teu vocabulário português.

Não te estragues com os elogios alheios senão vais parar na "P T"! Sabes o que é isso? Não mandes perguntar, seria $\mathrm{m}^{\text {to }}$ indiscreto.

Tenho certeza de que teu pai não te deixará ir a Paris.

" $\mathrm{B}$ ” devia ficar noivo no domingo, mas parece que ainda não teve coragem para pedir. Porém, o namoro continua firme e tu chegarás a tempo para o casamento.

As fotografias que pedes não estão comigo, isso é lá com a “GW”, que mora agora no 35 (sua ex-noiva).

Não tenho fotografias, pois sou de opinião de que gente feia não tira, nem dá retratos. Só num caso excepcional de loucura louca.

Roupa suja lava-se em casa, estou de acordo contigo, por isso que não deves contar tuas aventuras, frequências... etc., a ninguém. Só a nós. Senão te metem as botinas, como nos retratos de bailarino nu. "B” está na calma. Esteve de cama com doença de fígado. Ficou amarelo. Das conquistas, nada sei. "G" continua imaginando uma cousa que nunca existiu. Não há como a ilusão. Estou esperando você para tirar-lhe isto da cabeça. Os domingos estão desanimadíssimos. $\mathrm{M}^{\mathrm{to}}$ frio e tardes ventosas. O Jockey continua a ser o ponto de reunião da elite carioca. Depois das corridas há chá dançante. Até tia "S" saiu da toca e lá apareceu com as "M". Tia "J" sempre a mesma carne e osso com a "Z". Tia "B” está mº gentil e continua em Petrópolis. Os ânimos sempre exaltados. Mas as encrencas continuam as mesmas. A vitrola funciona sob as mãos de Melle "W".

"G" está fazendo furor em Santos. O "M" lá trabalha e continua apaixonado por ela. “A” está a tua espera. “A de "P”, vendendo as célebres margaridas de todos anos. Fomos convidadas para vender medalhas de Therezinha; não aceitamos. Não somos molecas de rua. O Golf-Club é lindo. Mas é bom para quem paga, somos sócios, mas lá não vamos. Não tenho retrato, mas mando-te este para mostrares aos teus colegas, um lindo e pitoresco recanto da fazenda do Lutterback (?). Ele me presenteou com este, por ocasião de uma exposição de aves, a que fomos na semana passada. O patinho mais lindo sou eu.

Adeus, rasgue as minhas cartas e todas as outras. Se encontrar um só rabisco meu na tua mala, nunca mais nos falaremos.

Saudades a tua "V"..., mas cuidado com ela. Um grande saco cheio de amizade e $\mathrm{m}^{\text {tos }}$ abraços da

“O”.

(*) Código nosso para referências aos casos amorosos. (PEIXOTO, I933). 


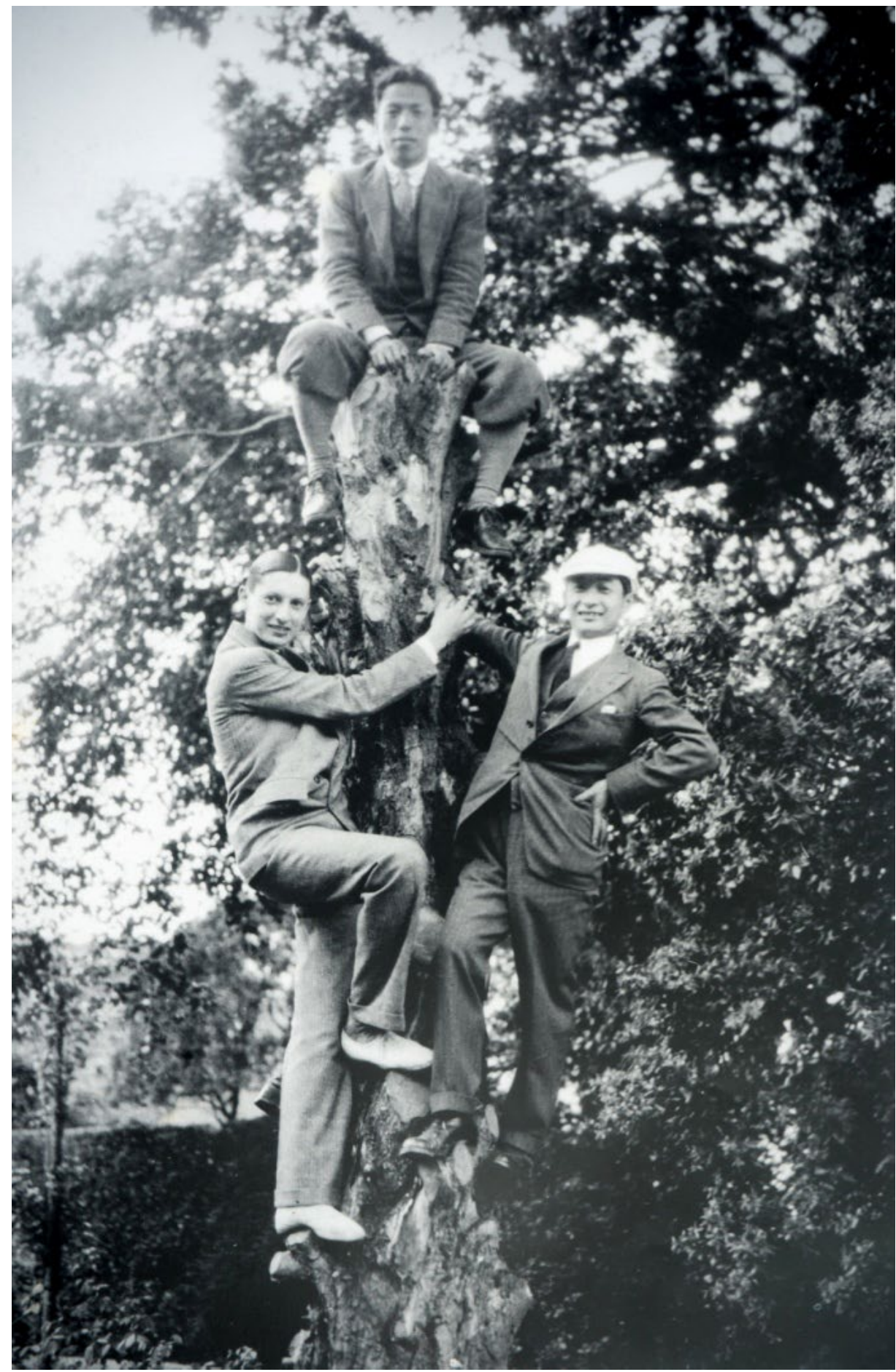

Figura I - Mário Peixoto com seus amigos Nishi e Hide, Inglaterra, I927. Arquivo Mário Peixoto, Rio de Janeiro 
Em I928, há uma última carta de $C$, talvez a prima Cornélia. O peso da família parece mudar. Mário Peixoto não parece aderir a só uma redenção pela leviandade que implicaria integrar não só as festas de seu meio social, mas também as suas exigências para achar um trabalho valorizado socialmente e um casamento. Se com a juventude, com as primas, Mário deixou de ser o monstro que julgava ser na infância, também pôde escapar ao papel que lhe parecia destinado.

Rio, 30 de abril de 1928

Mário!

Telefonei hoje para Petrópolis, e, fiquei muito aborrecida porque não pude falar contigo. Imagina que $4^{\mathrm{a}}$ feira vou dar um jantar de grande cerimônia, e necessito sem falta da tua pessoa.

Quero que venhas bem cedo, se possível pelo trem das 8, para que possas me ajudar um pouco nos arranjos e combinações.

Os "M" e mais alguns convidados virão jantar conosco, e, como é a primeira vez, quero uma coisa de "pose".

Somos I4 pessoas na mesa. Depois do jantar vamos dançar um pouco.

Quero que tragas sem falta a tua vitrola e as chapas de dança, para que possamos completar melhor a recepção.

Espero que não me negues coisa alguma, e que me telefones assim que esta chegar as tuas mãos a fim de combinarmos tudo direitinho.

Sei que estás doente, mas não faz mal. Saia um instante da cama e telefona-me sem falta, pois preciso imenso falar contigo.

Se eu tocar, não te chamam ao aparelho, é por isso que peço-te este favor.

Com um grande abraço, fico à espera de uma resposta bem urgente.

“C”2. (PEIXOTO, I933).

\section{SOBRE O AUTOR}

DENILSON LOPES é professor associado da Escola de Comunicação da Universidade Federal do Rio de Janeiro (ECO/UFRJ). noslined@bighost.com.br https://orcid.org/0000-0002-6306-5245 


\section{REFERÊNCIAS}

CARDOSO, Lucio. Crônica da casa assassinada. 9.ed. Rio de Janeiro: Nova Fronteira, 2017.

CASTRO, Amir de. Entrevista a Saulo Pereira de Mello. Arquivo Mário Peixoto, Io de fevereiro de I988.

Datilografado.

CASTRO, Emil de. Jogos de armar: a vida do solitário Mário Peixoto, o cineasta de Limite. Rio de Janeiro: Lacerda, 2000.

DOURADO, Autran. Ópera dos mortos. Rio de Janeiro: Rocco, I967.

DOURADO, Autran. Lucas Procópio. Rio de Janeiro: Record, I985.

DOURADO, Autran. Um cavalheiro de antigamente. São Paulo: Siciliano, I992.

GIDE, André. Se o grão não morre. Trad. Hamílcar de Garcia. Rio de Janeiro: Nova Fronteira, I982.

LACERDA, Rodrigo. Vista do Rio. São Paulo: Cosac Naify, 2004.

MIRANDA, Alcides da Rocha. Entrevista a Maria Celeste Lustosa. Rio de Janeiro. Arquivo Mário Peixoto. 5 de setembro de 1996. Datilografado.

MIRANDA, Alcides da Rocha. Entrevista a Maria Celeste Lustosa. Rio de Janeiro. Arquivo Mário Peixoto. I4 de setembro de I997. Datilografado.

MONTEIRO, Antonio da Nova. Entrevista concedida a Saulo Pereira de Mello. Rio de Janeiro, Arquivo Mário Peixoto, I5 de abril de I972. Datilografado.

PEIXOTO, Mário. Limite, I93I.

PEIXOTO, Mário. Cadernos verdes. Rio de Janeiro: Arquivo Mario Peixoto, I933. Datilografado.

PEIXOTO, Mário. O inútil de cada um. Rio de Janeiro: Record, I984..

PEIXOTO, Mário. Mundéu. Rio de Janeiro: Sette Letras, I996.

PEIXOTO, Mário. Entrevista a Vicente de Albergaria de Mangaratiba. Rio de Janeiro. Arquivo Mário Peixoto. Sem data.

PEIXOTO, Wilma Ferreira Alves. Entrevista a Maria Celeste Lustosa. Rio de Janeiro. Arquivo Mário Peixoto: 5 de outubro de I998. Datilografado.

RESENDE, Maria Eugênia Barbosa de. Conversa telefônica com Maria Celeste Lustosa. Rio de Janeiro, Arquivo Mário Peixoto, 24 de novembro de I997. Datilografado. 